\title{
Education for Academic Librarianship
}

A MERICAN HIGHER education today is at the crossroads. ${ }^{1}$ The immense problem of formulating a program of post-secondary education for our future intellectual leaders is challenging and perplexing. During the next quarter century major questions involving financial support, the curriculum, physical facilities, and national utilization of trained personnel will be resolved. How these questions are resolved will inevitably affect academic libraries in many ways. We can safely conclude that our service standards are seriously jeopardized unless we can marshal more imaginative thinking and ingenuity than we have marshalled in the first decade of the postwar period.

Service standards of the future will rest on our ability to meet the general and personal library needs of students and faculty. To some extent increased enrollment will result in an increase in the size of the faculty. If industry and government continue to siphon off a high percentage of the graduates of advanced programs, even an increase in the number of students in our doctoral programs will not supply the demand for college teachers. If an acute shortage of college teachers develops, the methods adapted by college and university presidents to cope with the problem could throw more of the burden of instruction on librarians by placing greater reliance upon library materials

1 Paper presented at the Eastern College Librarians Conference, Columbia University, November 30, 1957.

$D r$. Yenawine is Director of the Libraries and the Library School, Syracuse University. as sources of information and media for independent study. No doubt, an enlarged student body and faculty will increase demand for materials and professional library services. In turn academic libraries must find qualified librarians for expanded staffs.

If we assume that our present structure of professional education continues, library schools will continue to be a principal source of professional staff members. Library school directors and academic librarians have a common interest in the problems of recruitment, curriculum, and placement. This discussion concerns an analysis of some current aspects of these common problems from the points of view of the administrator and the library educator. Generalizations are based on data collected by questionnaires from a representative sample of academic librarians and from most of the library school directors.

College and university librarians today are operating 10 per cent below budgeted staff. Conservatively estimated, there are between 500 and 800 unfilled positions in academic libraries. College libraries with their smaller staffs have fewer vacancies than the medium sized or larger university libraries, but their problem is a more acute one because it is more difficult for them to compensate for the staff shortage and they are not in a financial position to compete with the larger libraries for available replacements. Vacancies are created by retirements and resignations. In 1956, 10 per cent of the vacancies that occurred were not filled, and by September, 1957, the situation did not improve. Some 
positions vacated were abolished, but this slight advantage was more than balanced by the new positions established to take care of increasing work loads, to implement expanded services, and to staff new buildings. In the past ten years, the number of staff members has increased about 50 per cent. Librarians expect their staffs to increase another 25 per cent in the next decade. There is evidence to believe that half of the academic libraries in the country will increase their staffs 50 per cent and expansion is projected by college and university libraries alike.

Turnover of staff members in academic libraries generally appears to be about 15 per cent annually, and librarians have had the greatest difficulty filling such positions as: cataloger, science librarian, reference librarian, documents librarian, administrator (associate librarian or head of department), subject specialist in charge of special collections, archivist, and junior professional assistant. While most librarians report prolonged and frustrating searches for catalogers, science librarians, etc., any unfilled professional position is a serious replacement problem.

Today administrators are obtaining more replacements from unsolicited applicants than they are from candidates recommended by library schools. Ten years ago, administrators more frequently relied on library schools for the names of prospective applicants and through their cooperation administrators received more help from library schools in filling vacancies than they did from any other source. A librarian can unquestionably choose the type of library, kind of library work, location, and climate he wishes. Apparently librarians are neither shy nor retiring about asking for what they want and frequently take the initiative in changing positions.

In locating replacements most aca- demic library administrators have relied at various times on advertisements, suggestions from librarians within and outside the staff, national or local placement agencies, and civil service registers. Many administrators have filled vacancies by appointing librarians with whom they were personally acquainted and by recruiting individuals who were professionally educated after appointment. Such methods of locating replacements are not new, but as the supply of candidates from library schools has trailed demand, they are all assuming a greater importance in the replacement picture. The sources ranked in order of importance to administrators in filling vacancies are as follows: unsolicited applications, library school recommendations, advertisements, staff suggestions, professional colleagues, national and local placement agencies, recruiting, and civil service registers.

The largest and many of the smaller university libraries have appointed librarians who are also subject specialists. They may be departmental and college librarians, catalogers of special fields, curators of special collections, or bibliographers responsible for the selection and acquisition of highly specialized materials. Some college librarians also have appointed librarians with training in subject fields to curatorships of special collections. In some libraries, there has been a deliberate attempt to develop the reference staff as a group of subject specialists. The present subject specialization in academic libraries is widespread, and administrators expect an increase in the number of positions requiring librarians who are familiar with the literature and research methods peculiar to special fields of knowledge.

In spite of personnel shortages, turnover, and the difficulties in finding replacements, the standards for selection of professional personnel are high. 
In general, administrators require the M.S. in L.S. degree from an accredited library school as a minimum qualification for professional appointment. Its equivalent is sometimes expressed in terms of a baccalaureate degree plus experience or training in library science. Personnel policies in some of the larger libraries involve requirements of linguistic skills. Administrators do not expect a change in minimum standards for professional appointment.' However, the librarians of some of the smaller college libraries report that "we are being forced to swing away from rigid requirements for our library staff positions due to the shortage. ... We now have an excellent librarian who is not a library school graduate."

Academic librarians are reasonably well satisfied with the graduates of the fifth-year master's program of professional education. At least there is general acceptance of the product of our American method of preparing librarians. Without alternative plans, it cannot be assumed that acceptance of the product vindicates the method and perhaps more feel, as one librarian did, when he wrote that "not much can be accomplished in one year. If the student attains a degree of professional weltanschauung and missionary attitude, that's about all we hope for from library schools." Granted that a librarian cannot learn all he needs to know about librarianship in a one-year program, he can and does apparently make a place for himself in academic libraries.

Library schools are not without critics among academic librarians, of course. While one librarian complains that library school graduates are "inadequately trained to take supervisory position," another one thinks the schools are "training too many chiefs and not enough Indians." While one librarian feels that library school graduates have an "insufficient knowledge of the theory and philosophy behind library techniques," another feels that "beginning catalogers show the lack of drill in fundamentals." While one librarian objects to how little the library school graduate knows about the content of books, another librarian bemoans the fact that graduates lack a broad knowledge of bibliographic titles and sources. Such conflicting opinion is understandable, but the library school is not likely to find much help in the criticism. Administrators do feel that too many library school graduates are lacking in imagination, initiative, maturity and a sense of professional ethics. Some librarians deplore the library school graduate's inadequate understanding of research methods and knowledge of the history of books and libraries. No doubt certain of these deficiencies are corrected with experience or continuing independent professional education. If librarians were plentiful, administrators could more often find the person who had just the right qualifications. However, in a period when the demand for professional librarians exceeds the supply, administrators too often have to compromise for someone neither the least nor most desirable. Some unhappiness about the qualifications of recently appointed librarians is no doubt the result of selection practices.

From the reports of academic librarians, the supply of professional replacements emerges as a critical factor now, and it is apparent that the importance of this factor will not diminish in the years that lie immediately ahead. An adequate supply of librarians is largely dependent upon the vocational attractiveness of librarianship, the success of coordinated recruiting programs, and the statesmanlike leadership among library educators. As long as the library school is the agency in our national 
educational system responsible for the preparation of librarians, ${ }^{2}$ the library school can be expected to affect significantly the future of academic librarianship to the extent that it fulfills in number and quality of graduates required, reflects the needs of tomorrow in the curriculum, and effectively places graduates for maximum utilization in the profession.

During the past five years, library school enrollment of candidates for advanced degrees reached a peak in 1954 and then dropped back again. In the fall of 1957 enrollment was encouragingly, if not significantly, higher than it was the year before. In the last three years enrollment steadily increased at 40 per cent of the library schools, has see-sawed up and down in 42 per cent and has decreased at the rest of the schools. Each of these three groups includes schools of varying size. Twentyseven library schools in the United States reported enrollments for the first semester of 1957-58 ranging from eighteen students to 361. Although the average enrollment was eighty-five students, the alarming fact is that the median enrollment was only sixty-three students. ${ }^{3}$ Another alarming aspect of the picture is the fact that for the past five years, less than 60 per cent of the students enrolled in library schools have completed degree programs and graduated. By the combined efforts of all library schools in recent years, less than 1,500 graduates have been qualified for professional appointments each year, and academic libraries alone need half of 1956's graduates.

All of the library schools are eager to attract students whose previous academic training includes a concentration

\footnotetext{
2 This does not deny the fact that we also rely on programs of training abroad in which some of our librarians were prepared as well as on-the-job training by which some of our subject specialists have been prepared for professional duties.

${ }^{3}$ In most library schools, the ratio of part-time students to full-time students was three to one.
}

in one of the subject fields. Many of their information bulletins include statements about the career opportunities in librarianship for the professionally educated subject specialist. Today 14 per cent of the students enrolled for advanced degrees in library science have master's degrees in subject fields and 1.5 per cent have doctorate degrees in subject fields. In the fall of 1957 all but two of the library schools had students with master's degrees enrolled and almost half of the library schools had students with doctorates.

From the viewpoint of the library science educator, there is no significant difference in the pre-professional education required for academic librarianship and the pre-professional education required for any other type of librarianship. It must be remembered that a program of professional education has been developed on the following principles:

3. That the primary instructional objective of five-year program shall be to develop professional personnel grounded in the fundamental principles and processes common to all types of libraries and all phases of library service. 4. That instruction for specialized service in libraries may occupy a place in this basic program but not at the sacrifice of necessary general academic and professional preparation. ${ }^{4}$

All library school directors feel that the best academic preparation is a general (liberal arts and sciences) education with a strong major in a subject field. Library educators emphasize the desirability of concentration in a subject field, but place no more emphasis on the humanities than on the science and social science fields. A preference is felt for the fields distinguished by a scholarly

\footnotetext{
4 "Proposals for Accrediting Professional Programs; A Statement of Policy by the ALA Board of Education for Librarianship," ALA Bulletin, XLV (1951),
} 10 . 
tradition in contrast to the narrower, vocational fields, although the educator concedes that training in the latter fields occasionally has pertinence in academic libraries. There is general agreement among library school directors that students preparing for academic librarianship should have a fluent reading knowledge of foreign languages.

It must be recognized that these statements concerning pre-professional study are opinions only and that library schools have a very limited opportunity to control the pre-professional curricula of their students. Some effort is made to compensate for this handicap through control over admissions following the general policy:

That professional schools which do not have effective control over courses outside the professional curriculum through guidance or prescription shall be responsible for achieving overall objectives through selection of students and/or requiring relevant course work subsequent to admission to the professional school.5

Although positive evidence is lacking, it is safe to say that very few individuals have been denied admission to library schools or required to take relevant courses subsequent to admission because they presented inadequate academic preparation. In this period of intensive recruitment of library school students, the admissions officer is not likely to deny, for this reason, admission to a candidate who very likely is sponsored and perhaps financially supported by a library to which he has promised to return for staff appointment. To be sure, a great many students enroll in library schools without strong convictions about the type of library or phase of librarianship for which they want to prepare. Some will have had another vocational interest which influenced their college

I bid. programs, and very few will have been influenced by library school recommendations concerning pre-professional curriculum. Library school graduates too often do not realize (if in fact they realize at all) until they.are on the job that they are poorly educated at the collegiate level for academic librarianship. Inadequacies in educational background do not necessarily handicap the student in successfully completing the master's program in library science, although inadequacies do frequently account for a student's uneven performance in library school courses.

Once the student is enrolled in the library school's degree program, the library educator does exercise control over his professional program of study. The comments of academic library administrators concerning the product of the library school raise questions about the library school's educational objectives and the curriculum designed to achieve these objectives. Dr. Harold Lancour expressed the educator's point of view when he said that the present curriculum:

. . . is designed to produce recruits to the library profession who will have the basic knowledges, some technical skills, and a motivating philosophy for professional service. In an educational system which emphasizes principles rather than practice, drill training in specific techniques is less important than the imparting of an understanding of the role that the library and the librarian is to play in modern life. Routinized skill and artful practice come from experience. Modern library school faculties feel that these things can be learned best on the job. The truth is that library schools today do not pretend to produce a technician who will perform at optimum capacity the first day or the first week that he begins work in a library. The faculty of the library school is not thinking of the individual in his first year as 
a professional librarian so much as they are thinking of his career twentyfive years later. The real success of the teaching of a library school faculty will be determined by the quality of the individual as a member of the library profession at the peak rather than at the beginning of his career. 6

The professional curriculum consists of basic required courses in library science, and when the student declares his preference for academic librarianship, he is generally also required to take courses covering the administrative problems and organization of college and university libraries, special problems of cataloging and classification, government publications, and subject bibliography. A few library schools require courses in communications and documentation. Programming at this point is influenced by the student's aptitudes or interests in the service, the technical, or the administrative phases of academic librarianship. The sequence of courses often includes such courses as the History of Books and Libraries, ${ }^{7}$ Advanced Reference, Development of Library Resources, Reading of Adults, Audio-Visual Materials and Services, Theory of Cataloging and Classification, and Methods of Research. In addition to library science courses, a number of library schools require students preparing for academic librarianship to take courses in the fields of higher education and in management, usually offered outside the library school. Typical of these courses are American Higher Education, Organization and Government of Higher Education, Contemporary Philosophies of Higher Education, Intellectual History of the American People, Theory of Management, and Personnel Administration.

${ }^{\circ} \mathrm{H}$. L. Lancour, "American Library Education Today," Canadian Library Association Bulletin, XIII (1957), 289.

${ }^{2}$ One library school requires a course described as the History of Scholarly Libraries.
Until recently, the terminal professional degree awarded the graduate of a library school was the master's degree. Academic libraries had a potential supply of replacements from two library school programs: the B.S. in L.S. program and the master's program. The University of Chicago Graduate Library School pioneered alone for two decades with a doctoral program in library science, and it was not until after the postwar revolution in library education, that doctoral programs in library science were established at the University of Illinois, the University of Michigan, Columbia University and the University of California. The full impact of the latter programs on academic libraries has yet to be felt.

The present fifth year master's program is the principal source of academic librarians and library schools receive 31 per cent of the requests for help in filling vacancies from administrators of academic libraries. In June 1957, library schools sent 29 per cent of their graduates to academic libraries. Practically all of these new academic librarians met the minimum professional qualifications of an M.S. degree in library science. Less than one half of one per cent of the graduates of the library schools were awarded doctorate degrees in library science. Thus far the doctoral program in library science is not a very promising source for staff replacements in academic libraries.

The graduate who combines a sound undergraduate program and a year of professional study does not necessarily satisfy the library school director. Some graduates complete satisfactorily all requirements for a master's degree in library science, but the library school director knows these individuals are not likely to grow intellectually or professionally. Since testing techniques leave much to be desired, and the pressures 
to admit students are strong, some graduates will be disappointaing as academic librarians. Of much greater concern, however, is the inspired graduate who has the capacity and drive to make a real contribution to librarianship. His first position is a challenge and his enthusiasm is a priceless asset. His professional growth and development are largely dependent upon the orientation, guidance, and encouragement he receives on the job. It is here that the library school director believes that the academic librarian has a responsibility to continue the professional education begun in the library school. The "sink or swim" policy with new librarians is shockingly inconsistent with library school education and out of place in a period of personnel shortage.

All library schools are frustrated by the fast flood of requests for the relatively few graduates who are available for appointment, and with few exceptions, library schools are not satisfied with enrollment. The shortage of librarians is not a problem which library schools alone can solve. The recruiting of library school students is a professional problem. No librarian is exempt from responsibility. The time has passed when the academic librarian could feel satisfied if he occasionally influenced an outstanding student assistant to enroll in a library school. Now many academic librarians are working hard on recruitment, but not too many; and usually the same ones who are most vocal about the shortage of librarians, still sit back thinking as the hungry preacher did that "the Lord will provide." Likewise some library school directors rationalize a donothing policy on recruitment. One fortunate director reports that "Our student body is filled each year by the usual process of applications from interested candidates." Another director comments that "Direct recruitment of library schools seems to me to be questionable and certainly not fruitful. A working librarian is a far better recruiter than a college professor." A third director reports "We do not recruit: The University is not willing for its faculty members to spend university time and money on recruitment. The librarians should be doing the recruiting."

There is something to be said for the attitude that recruiting is the librarian's job. Educating is the teacher's job. However, this attitude sounds a little too aloof to be appropriate in a period of crisis. In general, library schools are hard at work too, on recruiting programs. These involve dissemination of information about librarianship and educational facilities, alumni activities, "feeder" programs, and sponsorship of high school student librarians associations. From the appearance of some recent library school publications it is quite apparent that they have learned how to convey information in print with eye appeal and readable copy. There has been a significant improvement in the effectiveness of information bulletins or catalogs. Eight of the library schools have published promotional brochures which are welcome additions to recruiting literature. Many of the schools are represented at high school convocations, high school and college career days, and meetings of local clubs. One library school sponsors an annual "recruitment day" on its campus. Bulletins, scholarship and fellowship announcements, and letters are the most frequently used media of communication, although some library schools also use newspaper releases about alumni appointments to prominent positions, TV flashes, and radio spot announcements.

Library schools are increasing the number of extension programs and workshops both on and off the campus, and these, in addition to the under- 
graduate programs in library science, are excellent recruiting media. The difficulties of equalizing the educational advantages of extension courses and resident programs of study are offset in part by the opportunity extension courses provide for training many who could not enroll in resident programs. The necessity of full-time employment, family responsibilities, etc., prevent many from enrolling as resident students.

However successful current recruiting efforts prove to be, library school directors observe that the cost of professional education is still an insurmountable handicap to many prospective librarians. In comparison to other professions, librarianship offers very little scholarship aid. In recognition of of critical manpower shortages, industrial leaders were alert enough to see that an increase in the number of scholarships would increase the number of trained persons available to them. $\mathbf{L i}$ brarians can also find the financial support for more scholarships. Experiments with the two-year, work-study program should be encouraged as another method of helping the student defray the cost of his professional education.

In conclusion, academic library administrators and library school directors recognize the acute shortage of librarians. The former no longer expect the library school alone to supply replacements for professional staff and the latter no longer rely solely on the librarian to send students. Both categories are contributing their talents and resourcefulness to the recruitment program and both are helping in their respective ways to improve the attractiveness of librarianship as a career. The replacement problem will continue to be acute until the number of high quality graduates from library schools significantly increases. In the meantime the extensive proselyting of librarians is like "robbing Peter to pay Paul," and the academic librarian who has a liberal budget is in the best position to attract replacements.

We live in an age of specialization, but academic librarians still have not decided whether they need the generally trained specialist or the specially trained generalist. Library schools are admitting as many students with master's and doctor's degrees in special fields as possible, but they have found no effective way of relating the recruitment of such students to the needs of academic libraries.

There is good reason to doubt the wisdom of luring into librarianship those specially trained for other professions, but at the same time, librarianship gains from the trained leadership transferred from the professions. Unfortunately, however, few academic libraries can attract leaders from the professions of teaching, law, medicine, engineering, and architecture. Granting the need for subject specialists in academic libraries, the library school cannot yet lure the successful practitioner from another profession with either the personal or material rewards of librarianship.

It is obvious that neither the academic library administrator or the library school director is sufficiently pleased with the graduate to be confident about admission policies or the curriculum of the library school. Yet these two seem poles apart; they are not agreed on the qualifications of recruits for professional training or on the nature and content of the curriculum. Some academic librarians criticize library schools but fail to advise or exert any influence on professional educational planning. Likewise some library school faculties studiously protect themselves from contact with practicing librarians in the belief that only in this way can they lead. Neither viewpoint is

(Continued on page 501) 
tion and general program including publications, state and regional chapters, and relations with other divisions and with ALA. This committee should be fully appointed by the time you read these words.

Ralph Ellsworth has consented to serve as chairman of the ad hoc Committee to Explore the Relationship between the Law Library and the University Library.

Alton Keller's ACRL Conference Program Committee reports a meeting held in Washington on September 25 with exciting possibilities for meetings, tours and free time. We expect (and will receive) a fine program from this committee for our meetings in the capital city in June.

The Committee on Standards, Felix E. Hirsch, chairman, is hard at work revising its draft of new college library standards in the light of valuable suggestions made in San Francisco and expects to present a revised draft to the ACRL Board of Directors in January.

As for section activities, the newly formed Rare Books Section is planning a pre-conference seminar in Charlottesville in June. It is also eager to attract to its sectional membership those who work with and/or who are deeply interested in rare books and manuscripts. I am greatly pleased and optimistic about this newest addition to the ACRL sectional family.
The Subject Specialists Section, enriched by the recent inclusion of the humanists and the social scientists, is broadening its program to meet the needs of all its members. The section has agreed upon its Bylaws, and plans to publish them shortly.

The University Libraries Section has a formidable array of worthwhile projects to work upon.

I was gratified to note, as I hope you were, the passage by the Congress of the National Defense Education Act of 1958, with an appropriation of $\$ 900,000,000$. ACRL and many other educational organizations supported this bill.

It now looks as though ACRL will be permitted to have a constitution as well as bylaws. The ALA Committee on Constitution and Bylaws is scheduled to present for adoption in Washington in June an amendment to Article VI of the ALA Bylaws which relates to the operation of divisions, which will probably include a statement making divisional constitutions permissive.

Finally, I want to say that ACRL is in a healthy condition. With many of our problems of reorganization behind us, we are now in a position to devote our major efforts to a vigorous pursuit of a multifaceted program designed to improve the services of college and research libraries.-Lewis $C$. Branscomb, ACRL President.

\section{Education for Academic Librarianship}

(Continued from page 486)

sound and creates barriers to an essential common understanding.

Opportunities exist within professional organizations for a closer contact of librarians and professional library educators. Both groups need to combine and correlate their experience, judgments, and ideas on recruitment, curriculum, placement, and planning. Cooperatively it would be possible to develop a more effective recruiting program and a superior educational program. Cooperatively it would be possible to develop procedures for evaluating the performances of graduates on the job and using the resulting data in more intelligent planning for the education of academic librarians. 